\title{
Investigation of heavy metals release from sediment with bioturbation/bioirrigation
}

\author{
Yi He, Bin Men*, Xiaofang Yang, Yaxuan Li, Hui Xu, Dongsheng Wang*** \\ State Key Laboratory of Environmental Aquatic Chemistry, Research Centre for Eco-Environmental Science, Chinese Academy of Sciences, Beijing 100085 , \\ China
}

\section{H I G H L I G H T S}

- DGT-Cu fluxes in pore water increased with the presence of chironomid larvae.

- Heavy metals were highly influenced by bioturbation/bioirrigation of loach.

- Organisms has significant impact on particulate heavy metals release from sediment.

- $\mathrm{Fe} / \mathrm{Mn}$ hydrous oxides may sorb or coprecipitate with $\mathrm{Cd}, \mathrm{Cu}, \mathrm{Zn}$ and $\mathrm{Pb}$.

\section{A R T I C L E I N F O}

\section{Article history:}

Received 19 January 2017

Received in revised form

16 May 2017

Accepted 21 May 2017

Available online 2 June 2017

Handling Editor: Martine Leermakers

\section{Keywords:}

Heavy metals

DGT

Bioturbation/bioirrigation

Bioaccumulation
G R A P H I C A L A B S T R A C T

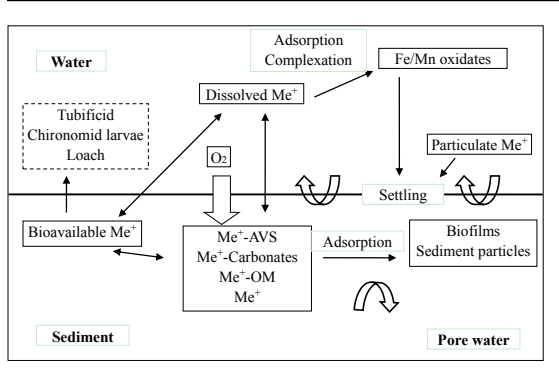

\begin{abstract}
A B S T R A C T
Bioturbation/bioirrigation can affect the remobilization of metals from sediments. In this study, experiments were performed to examine the effect of bioturbation/bioirrigation by different organisms on cadmium $(\mathrm{Cd})$, copper $(\mathrm{Cu})$, zinc $(\mathrm{Zn})$ and lead $(\mathrm{Pb})$ releasing from the spiked sediment. The diffusive gradient in thin films technique (DGT) revealed that at the end of exposure time, the labile heavy metals concentrations in the pore water for all metal and organisms combinations except $\mathrm{Cu}$ and chironomid larvae were much lower than that in the control group. However, the concentrations of heavy metals detected by the DGT were virtually indistinguishable among the treatments with tubificid, chironomid larvae and loach. The correlation analysis of heavy metals with iron ( $\mathrm{Fe})$ and manganese $(\mathrm{Mn})$ suggested that $\mathrm{Cd}, \mathrm{Zn}$ and $\mathrm{Pb}$ were most likely bound as Fe-Mn oxidation form in the pore water, but $\mathrm{Cu}$ was in other forms. After $28 \mathrm{~d}$ of exposure, bioturbation/bioirrigation produced a significant release of particulate heavy metals into the overlying water, especially in the treatment with loach. The bioturbation/ bioirrigation impact on the $\mathrm{Pb}$ remobilization was less than the other three heavy metals. The effects of bioturbaiton/bioirrigation on the heavy metals remobilization in the sediment were complex that with studying the heavy metals remobilization in the sediment and water interface, the biological indicators should be recommended.
\end{abstract}

๑) 2017 Elsevier Ltd. All rights reserved.

\footnotetext{
* Corresponding author.

** Corresponding author.

E-mail addresses: binmen@rcees.ac.cn (B. Men), wgds@rcees.ac.cn (D. Wang).
}

\section{Introduction}

The sediment which buried heavy metals may act as a source of contaminants with certain disturbances such as bioturbation/bioirrigation by benthic organisms (Banta and Andersen, 2003; Thibodeaux and Bierman, 2003; Granberg et al., 2008; Josefsson 
et al., 2010). Several studies have demonstrated that bioturbation/ bioirrigation can increase the transfer of heavy metals between sediment and water. Tubificid renewed the particles and adsorption sites for $\mathrm{Cd}$ at the interface of sediment and water, and also increased the Cd contents in the sediment layer (Ciutat et al., 2005). Hexagenia rigida nymphs lived in the contaminated sediment can also produce resuspention of large amounts of sediment particles rich in $\mathrm{Cd}$ and $\mathrm{Zn}$ into the water column (Ciutat and Boudou, 2003). There was strong $\mathrm{Cd}, \mathrm{Cu}$, and $\mathrm{Zn}$ mobilization by bioturbation/ bioirrigation of the Chironomus plumosus as their activities of digging into the sediments, and afterwards strong decrease of the three heavy metals concentrations, but to higher levels compared to values of treatments without invertebrate impact (Schaller, 2014). The polychaete Marenzelleria spp (Hedman et al., 2008) and carp (Wall et al., 1996) caused the high remobilization of Cd from sediment to the overlying water with the bioturbation/bioirrigation activities. The oligochaete worm Lumbriculus variegates can enhance $\mathrm{Pb}$ transfer across the interface of sediment and water and also enhance the availability of Pb (Blankson and Klerks, 2016). But some researchers found that bioturbation/bioirrigation may have little effect on the remobilization of heavy metals in the sediment. The presence of bivalve Tellina deltoidalis had little effect on the release of $\mathrm{Zn}$ and $\mathrm{Pb}$ from the sediment (Atkinson et al., 2007). The tubificid also provided little impact for the Pb remobilization from the sediment (Lv, 2009). The Hediste diversicolor did not influence the remobilization of dissolved mercury $(\mathrm{Hg})$ from the sediment to the water since the sediment was rich in organic matter content, $\mathrm{Fe} / \mathrm{Mn}$ total and hydrous oxides to retain the $\mathrm{Hg}$ in the sediment (Cardoso et al., 2008). And the bioturbation by Monoporeia affinis was also not sufficient to the release of $\mathrm{Cu}$ from the sediment enriched $\mathrm{Cu}$ (Ospina Alvarez et al., 2014). The different conclusions of the researches suggested that the influence of bioturbation/bioirrigation on the heavy metals fluxes in the sediment was very complex.

The bioturbation/bioirrigation effects on the heavy metals remobilization in the sediment were different with the different types of bioturbated organisms. The concentrations of dissolved $\mathrm{Cu}$ decreased and Mn increased with the presence of amphipod Victoriopisa australiensis compared with the presence only of bivalve Tellina deltoidalis for the different bioturbating intensity (Remaili et al., 2016). And the high bioturbation by Victoriopisa australiensis also produced significant release of DGT-labile $\mathrm{Cd}, \mathrm{Ni}, \mathrm{Pb}$ and Zn compared with the low bioturbation by Tellina deltoidalis in the pore and overlying water (Amato et al., 2016). The bioturbation tests with the burrowing Hexagenia sp. had consistently higher overlying water Ni concentrations compared with the amphipod (Hyalella azteca and Gammarus pseudolimnaeus) tests (Brumbaugh et al., 2013). Comparing the bioturbation by Tubifex tubifex and Chironomus riparius larvae on the release of uranium (U), the biotubation by T. tubifex led to a high degree of $U$ release from sediment into the overlying water for its effects on sediment reworking (Lagauzère et al., 2009). Until now, rare research exists evaluating the effect of the bioturbation/bioirrigation on heavy metals remobilization by different organism types, which can have great influence on the fate of heavy metals.

In fact, the toxicity and fate of metals in the sediments was obviously correlated with the partitioning of metals between the sediment particles and the pore water (Calmano et al., 1993; Chapman et al., 1998; Simpson, 2005). Bioturbation/bioirrigation can also change the concentrations of heavy metals in the sediment pore water. With the active burrowing by oligochaete Lumbriculus variegates, concentrations of $\mathrm{Cd}$ in pore water from deeper horizons were always lower than those in the surficial sediments without bioturbation (Peterson et al., 1996). The pore water Fe(II) was oxidized by benthic organism bioturbation to adsorb $\mathrm{Zn}$ as the formation of Fe hydroxide precipitates and result of lower $\mathrm{Zn}$ fluxes in pore water (Simpson and Batley, 2003). So it must pay attention to the concentrations of heavy metals in the pore water when study about the bioturbation/bioirrigation effects on the heavy metals remobilization in the sediment. The diffusive gradient in thin films (DGT) method can determine the average concentration in the interface of the sediment and solution within the placed time. With laboratory microcosm experiments, DGT may be a good method to investigate the bioturbation/bioirrigation effects on the changes of pore water heavy metal concentrations (Roulier et al., 2008; Simpson et al., 2012), and also it was a useful tool to assess the heavy metal bioavailability to benthic organisms in sediment (Amato et al., 2016). However, little work has been performed on the bioturbation/bioirrigation effect on the metal remobilization in the sediment pore water.

Three organisms were chosen for this study, including tubificid (Limnodrilus hoffmeisteri), chironomid larvae (Chironomus plumosus larvae), and loach (Misgurnus bipartitus), hereafter referred to as tubificid, chironomid larvae, and loach, respectively. Consequently, the present study aimed at the degree of bioturbation/bioirrigation effect on the heavy metals transfer processes by different types of riverine organisms. The heavy metals accumulated in the three organisms lived in the heavy metals spiked sediment was also investigated.

\section{Materials and methods}

\subsection{Sediment and water collection and preparation}

The sediment and water were sampled from the Ming Tombs Reservoir in the northwest of Beijing (China) in May 2013. The collected water were pre-aerated for $24 \mathrm{~h}$ and filtered through $0.45 \mu \mathrm{m}$ cellulose acetate membrane filter. The percentage of the particle size below $60 \mu \mathrm{m}$ of the sediment was $85.7 \%$. The $\mathrm{pH}$ value of the sediment was 7.6. The sediment was rich in organic matter that the loss by ignition was $7.9 \%$ (He et al., 2015). Wet sediment was added to plastic mixing containers and then spiked with analytical reagent grade of $\mathrm{Cd}\left(\mathrm{NO}_{3}\right)_{2} \cdot 4 \mathrm{H}_{2} \mathrm{O}, \mathrm{ZnSO}_{4} \cdot 7 \mathrm{H}_{2} \mathrm{O}, \mathrm{Pb}\left(\mathrm{NO}_{3}\right)_{2}$ and $\mathrm{CuSO}_{4} \cdot 5 \mathrm{H}_{2} \mathrm{O}$ successively. During the first 2 months, the test sediment was stirred twice a week at room temperature in order to make it homogenized. The final $\mathrm{Cd}, \mathrm{Cu}, \mathrm{Zn}$ and $\mathrm{Pb}$ concentration of sediment after spiking in each experiment unit was $11.3 \pm 1.4 \mathrm{mg} \mathrm{kg}^{-1}, 881.1 \pm 68.9 \mathrm{mg} \mathrm{kg}^{-1}, 1132.8 \pm 86.3 \mathrm{mg} \mathrm{kg}^{-1}$, and $875.8 \pm 70.4 \mathrm{mg} \mathrm{kg}^{-1}$ (dry mass, $\mathrm{n}=16$ ), respectively.

\subsection{Experimental design and setup}

The experiments of the bioturbation/bioirrigation effects on the heavy metals releasing from the spiked sediment were conducted the same as previous study (He et al., 2015). The experiments were conducted for $29 \mathrm{~d}$ in glass beakers with diameter of $13 \mathrm{~cm}$ and height of $19 \mathrm{~cm}$ which were lined with high density polyethylene film. $600 \mathrm{~mL}$ water and about $2.0 \mathrm{~kg}$ contaminated sediment were added into each beaker. Four series of treatments with four replicates were conducted. The first treatment was a control group without organism adding, the other three series of treatments contained $2.0 \mathrm{~g}$ of different organism, respectively. The number of tubificid, chironomid larvae and loach as $7.5 \times 10^{5} \mathrm{~m}^{-2}$, $9.4 \times 10^{4} \mathrm{~m}^{-2}$, and $1.5 \times 10^{2} \mathrm{~m}^{-2}$ respectively. After $28 \mathrm{~d}$ of the exposure time, the survival rate of tubificid and chironomid larvae was about $70 \%-90 \%$, and the loach were all survived. The main research contents were the dissolved and particulate heavy metals concentrations, $\mathrm{pH}$ value, and turbidity in the overlying water during the exposure time. In addition, the concentrations of heavy metals in the pore water were studied by the DGT (Lancaster 
LA20QJ, UK) samplers which were deployed in the units on the 28th $\mathrm{d}$ after sampling in overlying water, following established procedures (Limited). As the DGT shape, the devices were insert vertically in the sediment about $10 \mathrm{~cm}$ depth, and the rest in the overlying water was about $4 \mathrm{~cm}$. Concentrations determined by DGT were calculated by the well-documented procedures and equations according to literature (Denney et al., 1999; Buzier et al., 2006).

The experiment of bioaccumulation of the heavy metals by the three organism was similar as the method used before (He et al., 2015). The experiment was performed in plastic beakers with the diameter of $10 \mathrm{~cm}$. Each beaker consisted of contaminated sediment $(1 \mathrm{~cm}$ depth), water column $(300 \mathrm{~mL})$ and $1.0 \mathrm{~g}$ of organisms. Three bioaccumulation treatments (with tubificid, with chironomid larvae, and with loach) were conducted with four parallel groups. The surviving organisms were collected after $3,5,7,10,14,21$, and $28 \mathrm{~d}$ to measure the accumulation concentration of $\mathrm{Cd}, \mathrm{Cu}, \mathrm{Zn}$ and $\mathrm{Pb}$. The collected organisms were cultured in the clean tap water for $6 \mathrm{~h}$. Then rinsed with Milli-Q water at least three times and freezedried (FD-1A, Beijing Bo Kang Experimental Medical Instrument Co., Ltd.) before they were ready for microwave digestion with aqua regia.

$\mathrm{Cd}, \mathrm{Cu}, \mathrm{Zn}$ and $\mathrm{Pb}$ analyses were all conducted by inductively coupled plasma mass spectrometry (ICP-MS) (7500a). Fe and Mn were measured by inductively coupled plasma atomic emission spectrometry (ICP-AES) (Prodigy).

\subsection{Data analysis}

The data were prepared using Excel 2000. Statistical analyses of the data by using Origin 9.0 and SPSS Base 15.0 software. The correlation between $\mathrm{Fe} / \mathrm{Mn}$ and $\mathrm{Cd}, \mathrm{Cu}, \mathrm{Zn}$, and $\mathrm{Pb}$ was performed on plots of the concentrations of them in the pore water.

\section{Results}

\subsection{DGT concentrations of heavy metals}

The vertical distribution of heavy metals concentrations in the pore water after $28 \mathrm{~d}$ detected by the DGT was shown in Fig. 1, the " 0 " represented the sediment-water interface.

The DGT concentration of Cd (Fig. 1a), Cu (Fig. 1b), Zn (Fig. 1c), and $\mathrm{Pb}$ (Fig. 1d) in the pore water ranged from 11.3 to $36.6 \mu \mathrm{g} \mathrm{L}^{-1}$, 27.6-49.2 $\mu \mathrm{g} \mathrm{L}^{-1}, 75.9-155.9 \mu \mathrm{g} \mathrm{L}^{-1}$, and $12.0-40.0 \mu \mathrm{g} \mathrm{L}^{-1}$ in the control group, respectively; from 7.8 to $28.6 \mu \mathrm{g} \mathrm{L}^{-1}$, 22.7-54.5 $\mu \mathrm{g} \mathrm{L}^{-1}, 50.8-163.5 \mu \mathrm{g} \mathrm{L}^{-1}$, and $7.9-32.7 \mu \mathrm{g} \mathrm{L}^{-1}$ in the tubificid group, respectively; from 6.8 to $29.8 \mu \mathrm{g} \mathrm{L}^{-1}$, 42.2-69.4 $\mu \mathrm{g} \mathrm{L}^{-1}, 98.3-183.4 \mu \mathrm{g} \mathrm{L}^{-1}$, and $7.0-33.5 \mu \mathrm{g} \mathrm{L}^{-1}$ in the chironomid larvae group, and from 8.1 to $29.2 \mu \mathrm{g} \mathrm{L}^{-1}$, 21.7-37.8 $\mu \mathrm{g} \mathrm{L}^{-1}, 41.3-165.3 \mu \mathrm{g} \mathrm{L}^{-1}$, and $8.5-34.0 \mu \mathrm{g} \mathrm{L}^{-1}$ in the loach group, respectively. DGT-Cd concentration in the control group had a peak at $6 \mathrm{~cm}$ depth, while concentrations detected by the DGT $\left(C_{D G T}\right)$ of biological groups at this depth were lower. Only at 5 and $8 \mathrm{~cm}$ depth, DGT-Cd concentrations of biological groups were higher than that of the control group. The peak of DGT-Cu concentrations was at $1 \mathrm{~cm}$ depth in both the control and chironomid larvae group, at $8 \mathrm{~cm}$ depth in the tubificid group, and at $2 \mathrm{~cm}$ depth in the loach group. DGT-Zn concentrations in the control group had a peak at $3 \mathrm{~cm}$ depth, at $8 \mathrm{~cm}$ depth in the tubificid group, and at the $4 \mathrm{~cm}$ depth in both the chironomid larvae and loach group. DGT-Pb concentrations in the control, tubificid and chironomid larvae group had a peak at $6 \mathrm{~cm}$, and at $5 \mathrm{~cm}$ depth in the loach group.

\subsection{Heavy metals in the overlying water}

The concentrations of dissolved and particulate heavy metals in the overlying water were shown in Fig. 2. Concentrations of dissolved Cd (Fig. 2a) and Zn (Fig. 2e) with the treatments of bioturbators were higher than that in the control group at the beginning of the experiment, but at the end of the exposure time, only the dissolved $\mathrm{Cd}$ and $\mathrm{Zn}$ concentrations in the tubificid group, and the dissolved $\mathrm{Zn}$ concentrations in the chironomid larvae groups were higher than that in the control group. The dissolved $\mathrm{Cu}$ (Fig. 2c) concentrations changed gradually, except that in the loach group increased with time and was higher than that in the control group at the end of experiment. The concentrations of dissolved $\mathrm{Pb}$ (Fig. 2g) only in the loach group were higher than that in the control
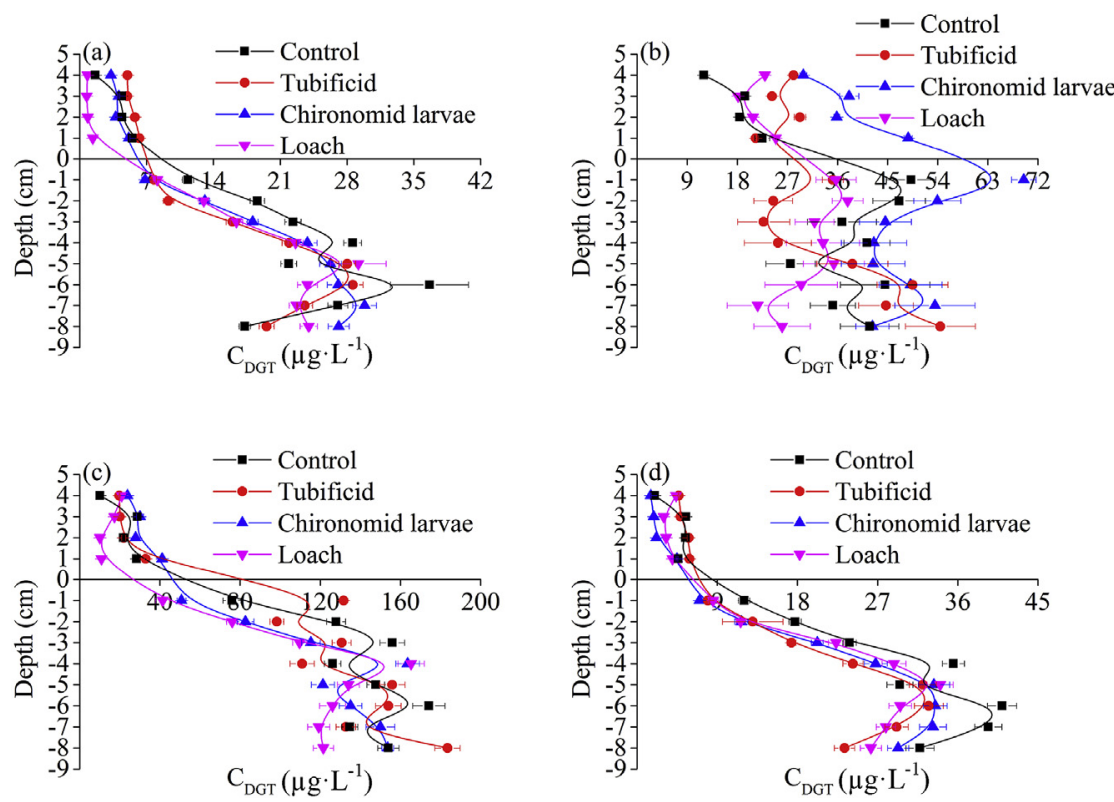

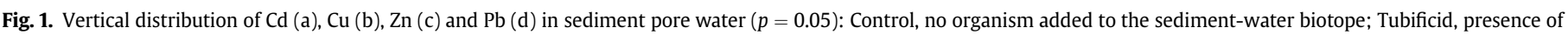
tubificid; Chironomid larvae, presence of chironomid larvae; Loach, presence of loach. 

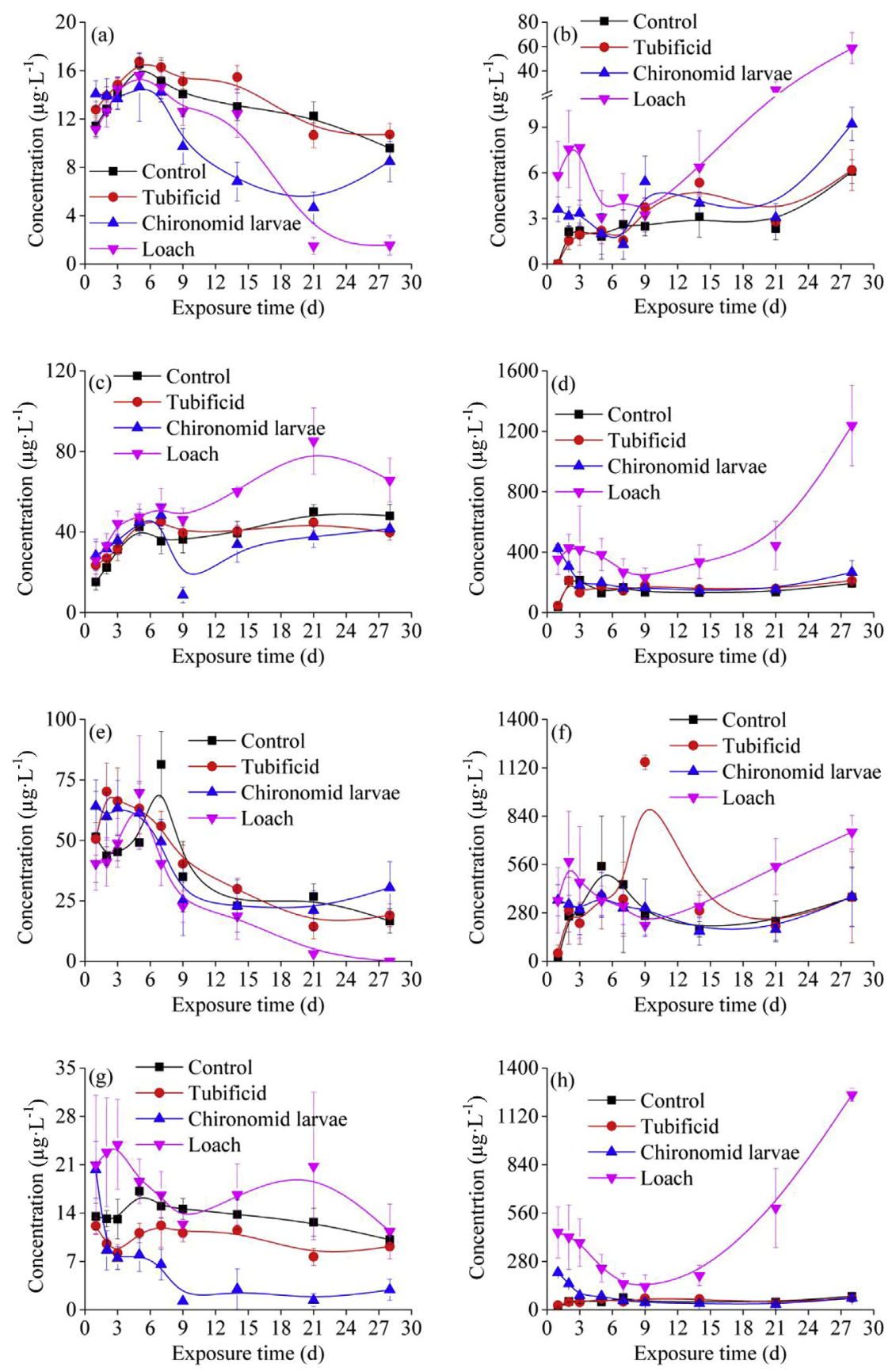

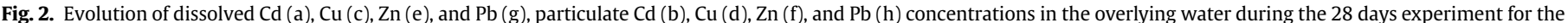

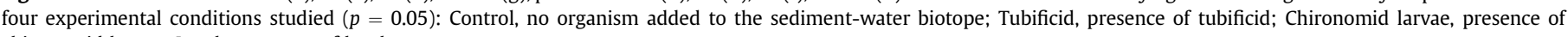
chironomid larvae; Loach, presence of loach.

group. Concentrations of particulate Cd (Fig. 2b), Cu (Fig. 2d), Zn (Fig. 2f), and $\mathrm{Pb}$ (Fig. 2h) in the loach group were much higher than that in the control group, but the other treatments with organisms had the similar change trend as that in the control group.

\subsection{Heavy metals accumulated in the three organisms}

Heavy metals accumulated in the three organisms with the exposure time was shown in Fig. 3. Tubificid had the best accumulated ability for Cd (Fig. 3a), Cu (Fig. 3b), Zn (Fig. 3c), and Pb (Fig. 3d), followed with chironomid larvae and loach. After $10 \mathrm{~d}$, the heavy metals concentrations in the tubificid body reached the equilibrium. While the accumulated $\mathrm{Cd}, \mathrm{Cu}$, and $\mathrm{Zn}$ concentrations in the chironomid larvae body needed only $3 \mathrm{~d}$ to reach the equilibrium, and the $\mathrm{Pb}$ concentration in the organism increased during the first $5 \mathrm{~d}$, then decreased with the exposure time. Loach had the poor accumulation ability for the heavy metals, especially on the 7 th $\mathrm{d}$, the $\mathrm{Zn}$ concentration in the organism was lower than the original bioconcentration in loach at the beginning of the experiment.

\section{Discussion}

The peak of DGT concentrations of heavy metals in the pore 

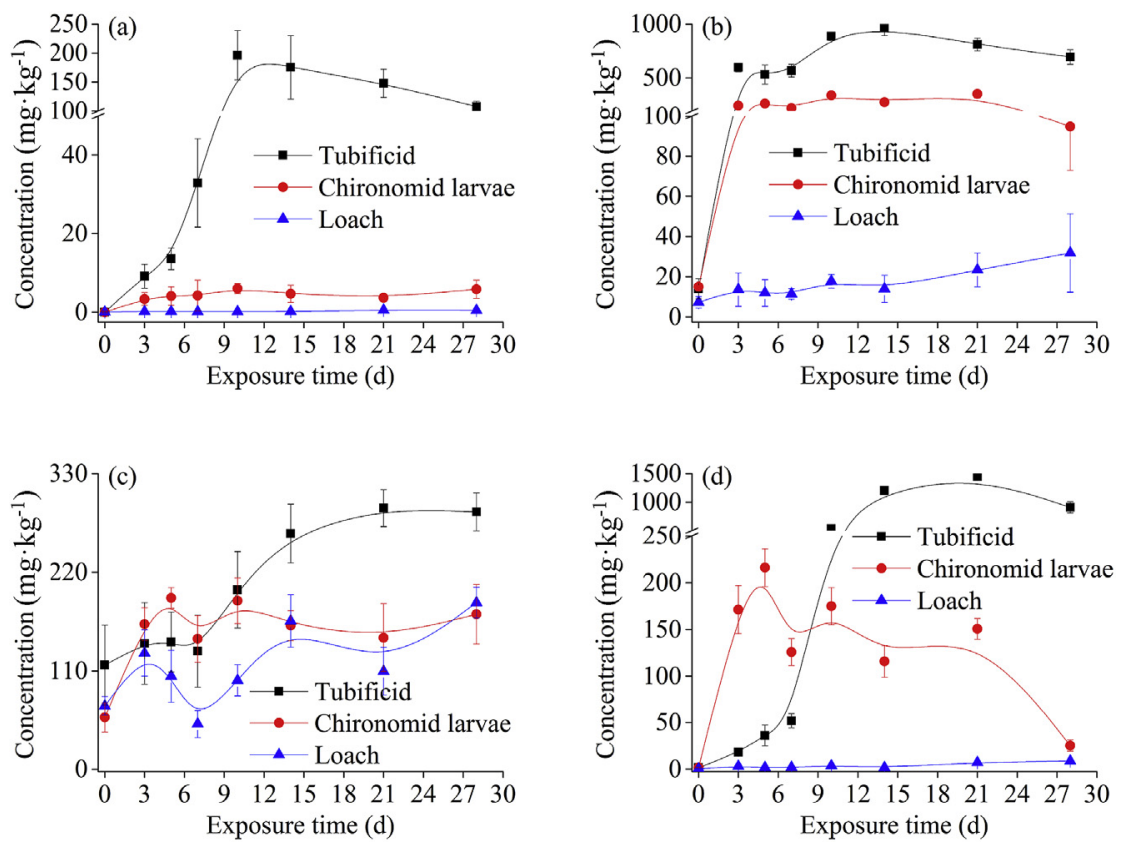

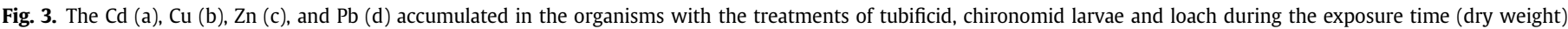
$(p=0.05)$.

water of the biological groups were as follows: $\mathrm{Cd}$, chironomid larvae > loach > tubificid; Cu, chironomid larvae > tubificid > loach; $\mathrm{Zn}$, chironomid larvae $>$ loach $>$ tubificid; and $\mathrm{Pb}$, loach $>$ chironomid larvae $>$ tubificid. And the $\mathrm{Cd}, \mathrm{Zn}, \mathrm{Pb}$ concentrations in the pore water of the biological groups were lower than that in the control group. Bioturbation/bioirrigation process can loosen the sediment, and increase the sediment surface with more sorption sites for heavy metals, resulting in the heavy metals bind onto the sediment, which tends to bring down the heavy metals levels in pore water. On the other hand, adsorption of continious forming biofilm on the sediment particle and biological absorption (Schaller et al., 2010) for the heavy metals can be another reason for the lower concentrations of heavy metals in the pore water of biological groups compared to the control group. In addition, the respiratory and feeding purposes of the organisms caused open- or blind-ended burrows to enhance the transport of solutes out of burrows to the overlying water (Kristensen, 2001; Shull et al., 2009), and also introduced the overlying water to dilute the heavy metals concentrations in the pore water. DGT-Cd from the deeper horizons out of the burrowing zone were consistently lower than those in the surface sediments which was the same with the previous study (Peterson et al., 1996). The case that concentration of DGT-Cu in the chironomid larvae group was higher than it in the control group. This may be due to the bioturbation/bioirrigation by chironomid larvae which caused higher oxidation reduction potential (ORP) with strong oxidizing at the same depth of sediment, then the $\mathrm{Cu}$ existed as the dissolved forms for $\mathrm{CuCl}^{2+}, \mathrm{CuCl}_{3}^{2+}(\mathrm{Ma}$ and Wan, 1999). While the bioturbaiton/bioirrigantion had little effect on $\mathrm{Pb}$ remobilization which was a stable element. Previous study also showed that the bioturbation effect was not significant on $\mathrm{Pb}$ in the deeper sediment (Qiao, 2011).

In the control group, the dissolved $\mathrm{Cd}, \mathrm{Cu}, \mathrm{Zn}$ and $\mathrm{Pb}$ in the overlying water were the result of the simple molecular diffusion from the sediment pore water. The strong increase of $\mathrm{Cd}, \mathrm{Cu}, \mathrm{Zn}$ and $\mathrm{Pb}$ in the overlying water with the treatments of organisms during the early of exposure time can be explained by the effects from burrowing (dig in) of the tubificid and chironomid larvae into the sediment. DGT will measure all those species that are in labile equilibrium with the species that can bind to the binding agent. In this study, the correlation between heavy metals with Fe and Mn detected in DGT device (Fig. 4) showed that they had a strong positive correlation except $\mathrm{Cu}$, indicating that $\mathrm{Cd}, \mathrm{Zn}$, and $\mathrm{Pb}$ were most likely bound as Fe-Mn oxidation form in sediment pore water, but $\mathrm{Cu}$ was in other forms. Previous literature demonstrated that $\mathrm{Fe}$ and Mn oxy-hydroxides were important parts for adsorbing heavy metals in freshwater oxic sediments (Tessier and Campbell, 1988; Luoma, 1989; Tessier et al., 1993). In this study, the correlation between heavy metals and Fe, Mn DGT concentrations stressed the importance of Fe and Mn (hydr)oxides for carrying heavy metals in the pore water.

Without the bioturbation/bioirrigation, the dissolved $\mathrm{Cd}, \mathrm{Cu}, \mathrm{Zn}$ and $\mathrm{Pb}$ in the overlying water were the result of the simple molecular diffusion from the sediment pore water. The strong increase of $\mathrm{Cd}, \mathrm{Cu}, \mathrm{Zn}$ and $\mathrm{Pb}$ in the overlying water with the treatments of organisms during the early of exposure time can be explained by the effects from burrowing (dig in) of the tubificid and chironomid larvae into the sediment, and the swimming of loach at the surficial sediment. This is in accordance with previous study by Schaller (2014). With bioturbation/bioirrigation, oxygen can penetrate deep into the sediment, the heavy metals presence in the form of acid-volatile sulfides (AVS) may resolve into the dissolved phase by the sediment oxidation, and then diffuse across the sedimentwater interface (Ciutat and Boudou, 2003). Additionally, increased oxygen concentration of sediment can increase the solubility of $\mathrm{Cd}$ and Zn (Gambrell et al., 1991), and the stronger bound oxidizable fractions of $\mathrm{Cd}, \mathrm{Cu}, \mathrm{Zn}$ and $\mathrm{Pb}$ changed to weaker bound carbonate and exchangeable fractions of these heavy metals with the increased oxygen content of sediment (Calmano et al., 1993; Zoumis et al., 2001), so the dissolved $\mathrm{Cd}, \mathrm{Cu}, \mathrm{Zn}$ and $\mathrm{Pb}$ concentrations increased. And bioturbation/bioirrigation can enhance the heavy metals exchange rates between overlying water and pore water by increasing the contact zone of sediment and water (Lewandowski and Hupfer, 2005), resulting in the release of heavy metals into the water. In this study, the $\mathrm{Cd}, \mathrm{Cu}, \mathrm{Zn}$ and $\mathrm{Pb}$ migrated 

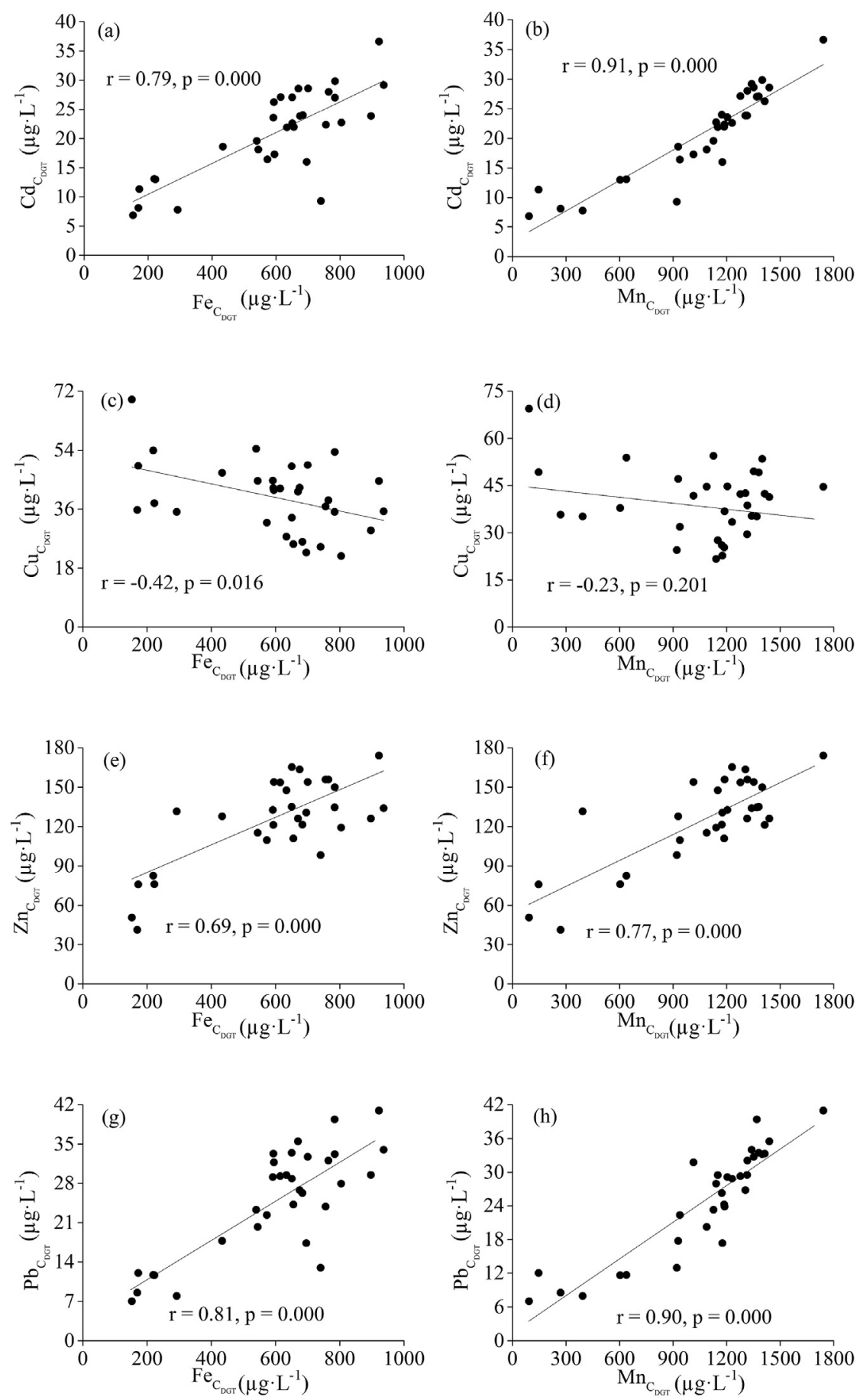

Fig. 4. The linear correlation analysis between Fe, Mn and heavy metals in the sediment pore water detected by the DGT.

to the overlying water were dominated in particulate form (Rasmussen et al., 2000; Lv, 2009; Qiao, 2011), which was due to the resuspention of the sediment particles with the bioturbaiton/bioirrigation by the organisms.

However, the dissolved $\mathrm{Cd}, \mathrm{Cu}, \mathrm{Zn}$ and $\mathrm{Pb}$ concentrations in the overlying water decreased with the exposure time, this may be due to the precipitation and sorption processes to remove them from solution (Du Laing et al., 2009; Mostofa et al., 2013). The pH values of the overlying water (Table 1 ) in the bioturbation/bioirrigation groups increased after $5 \mathrm{~d}$ and achieved the maximum value (tubificid, $8.1 \pm 0.0$; chironomid larvae, $8.3 \pm 0.2$; loach, $9.1 \pm 0.4$ ) after $21 \mathrm{~d}$. The free $\mathrm{Cd}$ concentration decreased after $5 \mathrm{~d}$ and $\mathrm{Zn}$ decreased after $3 \mathrm{~d}$ may be due to the free $\mathrm{Cd}$ and $\mathrm{Zn}$ precipitated consequently with the high $\mathrm{pH}$ values in the overlying water. In some researcher's opinion, as the $\mathrm{pH}$ value increased, the first order of the hydrolysis of the heavy metals increased, so the metal hydroxyl complexes increased, the absorbed amount also increased (Boekhold et al., 1993). And there may be a better bond ability between the metal hydroxyl complexes and adsorption sites (Hodgson et al., 1964). The increase of $\mathrm{pH}$ value is propitious of combining of the points of double-proton and to increase the adsorption of heavy metals. Furthermore, the ionic-exchange 
Table 1

The $\mathrm{pH}$ and turbidity values in the overlying water during the exposure time.

\begin{tabular}{|c|c|c|c|c|c|}
\hline & \multirow[t]{2}{*}{ Exposure time $(\mathrm{d})$} & \multicolumn{4}{|l|}{ Treatment } \\
\hline & & Control & Tubificid & Chironomid larvae & Loach \\
\hline \multirow[t]{9}{*}{$\mathrm{pH}$} & 1 & $7.7 \pm 0.0$ & $7.5 \pm 0.1$ & $7.3 \pm 0.0$ & $7.5 \pm 0.1$ \\
\hline & 2 & $7.8 \pm 0.0$ & $7.6 \pm 0.1$ & $7.4 \pm 0.1$ & $7.6 \pm 0.1$ \\
\hline & 3 & $7.8 \pm 0.0$ & $7.6 \pm 0.1$ & $7.5 \pm 0.1$ & $7.7 \pm 0.1$ \\
\hline & 5 & $7.9 \pm 0.0$ & $7.7 \pm 0.1$ & $7.6 \pm 0.1$ & $7.7 \pm 0.0$ \\
\hline & 7 & $7.9 \pm 0.0$ & $7.8 \pm 0.0$ & $7.7 \pm 0.0$ & $7.7 \pm 0.0$ \\
\hline & 9 & $8.0 \pm 0.0$ & $7.9 \pm 0.0$ & $7.8 \pm 0.0$ & $7.7 \pm 0.0$ \\
\hline & 14 & $8.0 \pm 0.0$ & $7.9 \pm 0.0$ & $8.3 \pm 0.4$ & $7.8 \pm 0.1$ \\
\hline & 21 & $8.0 \pm 0.0$ & $8.1 \pm 0.0$ & $8.3 \pm 0.2$ & $9.1 \pm 0.4$ \\
\hline & 28 & $8.0 \pm 0.1$ & $8.1 \pm 0.0$ & $8.0 \pm 0.1$ & $9.0 \pm 0.2$ \\
\hline \multirow[t]{9}{*}{ Turbidity (NTU) } & 1 & $4.0 \pm 1.4$ & $9.7 \pm 2.1$ & $108.2 \pm 19.5$ & $789 \pm 76$ \\
\hline & 2 & $2.2 \pm 0.7$ & $6.1 \pm 2.1$ & $52.7 \pm 4.1$ & $464 \pm 71$ \\
\hline & 3 & $2.0 \pm 0.0$ & $5.1 \pm 0.9$ & $29.5 \pm 3.3$ & $299 \pm 47$ \\
\hline & 5 & $6.3 \pm 3.9$ & $6.8 \pm 2.3$ & $25.1 \pm 3.9$ & $251 \pm 137$ \\
\hline & 7 & $2.9 \pm 0.1$ & $3.8 \pm 1.3$ & $12.1 \pm 2.1$ & $143 \pm 3$ \\
\hline & 9 & $1.8 \pm 0.7$ & $2.2 \pm 0.5$ & $9.5 \pm 1.2$ & $25.6 \pm 5.3$ \\
\hline & 14 & $1.2 \pm 0.2$ & $1.7 \pm 0.3$ & $4.3 \pm 0.1$ & $211 \pm 68$ \\
\hline & 21 & $2.6 \pm 0.9$ & $6.9 \pm 1.1$ & $23.2 \pm 3.1$ & $870 \pm 123$ \\
\hline & 28 & $2.0 \pm 0.4$ & $6.7 \pm 1.5$ & $6.6 \pm 0.3$ & $1286 \pm 221$ \\
\hline
\end{tabular}

between $\mathrm{Cd}^{2+}$ and the layered silicate strengthen with the $\mathrm{pH}$ value increase (Inskeep and Baham, 1983). In addition, the Fe and Mn were well correlated with $\mathrm{Cd}, \mathrm{Cu}, \mathrm{Zn}$ and $\mathrm{Pb}$ in particulate form (Table 2). The newly formed Fe-Mn oxide in the suspended sediment particles tends to adsorb the free $\mathrm{Cd}, \mathrm{Cu}, \mathrm{Zn}$ and $\mathrm{Pb}$ (Turner et al., 2004), subsequently settled in sediment-water surface. The Fe oxides did the largest contribution to adsorb the $\mathrm{Cd}$, and $\mathrm{Mn}$ oxides did the largest contribution to adsorb Pb (Dong et al., 2000). Therefore, large amounts of suspended particles caused by bioturbation/bioirrigation provided much more absorptive surfaces for the heavy metals, so dissolved form concentrations of biological groups were lower than that of the control group and thereby reduce their mobility.

During the exposure time, the organisms were without food provisioning, they just lived with the organic detritus in the sediment. The acute lethal concentration of $50 \%\left(\mathrm{LC}_{50}\right)$ of $\mathrm{Cd}, \mathrm{Cu}, \mathrm{Zn}$ and $\mathrm{Pb}$ for tubificid, chironomid larvae, and loach was shown in Table 3 (Wang et al., 2003; Bechard et al., 2008; Maestre et al., 2009; Mendez-Fernandez et al., 2013; Zhu et al., 2014; Jiang et al., 2016), the studies showed that the three organisms had higher tolerance of $\mathrm{Cd}, \mathrm{Cu}, \mathrm{Zn}$ and $\mathrm{Pb}$. During the experiment, the concentrations of dissolved $\mathrm{Cd}, \mathrm{Cu}, \mathrm{Zn}$ and $\mathrm{Pb}$ were not beyond the $\mathrm{LC}_{50}$ values for the three organisms, so there would not turn up the acute death for the three organisms to avoid the phenomenon of no living organisms in the biological groups. According to the literature, the tubificid ingested sediment particles were the tiniest particles (Ciutat, 2003), which likely to have the highest heavy metals contents for their large surface-to-volume ratio, high organic carbon content, and high binding capacity of clay particles (Thorne and Nickless, 1981; Duquesne et al., 2006). Therefore, tubificid can accumulate significant quantities of heavy metals after exposure to contaminated sediment. The heavy metals accumulated in the chironomid larvae was lower than in the tubificid may be for that they can clean their body to avoid high concentrations of heavy metals by excreting ingested them (Tessier et al., 1994; Alves et al., 2009; Schaller et al., 2011). Loach had the worst accumulation ability to heavy metals, this less bioaccumulation perhaps due to its filter feeding behavior. The laboratory studies of metal uptake showed that concentration factors were higher in invertebrates than in vertebrates (Taylor, 1983), and some researchers found that the levels of heavy metals in the predators were lower than those with other feeding habits in the same habitats (Timmermans et al., 1989; van Hattum et al., 1991). Heavy metals can enter fish through the gills by passive diffusion or by entering through the diet (Bosch et al., 2016). Therefore, although the maximum total heavy metals concentrations in the overlying water was in the loach group, the bioaccumulation seemed the minimum among the three organisms.

\section{Conclusion}

Bioturbation/bioirrigation by different organisms of the spiked $\mathrm{Cd}, \mathrm{Cu}, \mathrm{Zn}$, and $\mathrm{Pb}$ sediments can enhance the transfer of soluble $\mathrm{Cd}$, $\mathrm{Cu}, \mathrm{Zn}$ and $\mathrm{Pb}$ from the pore water to the sediment or overlying water. The $\mathrm{Cd}, \mathrm{Zn}$ and $\mathrm{Pb}$ in the sediment pore water were most likely bound as $\mathrm{Fe}-\mathrm{Mn}$ oxidation form, and $\mathrm{Cu}$ was in other forms. The bioturbation/bioirrigation enhanced the quantity of suspended particles and lead a significant release of $\mathrm{Cd}, \mathrm{Cu}, \mathrm{Zn}$ and $\mathrm{Pb}$ to the overlying water, especially for the treatment with loach. The increased $\mathrm{pH}$ values in the overlying water by the bioturbation/

Table 2

Correlation analysis between Fe, Mn concentrations and concentrations of other heavy metals in the overlying water

\begin{tabular}{|c|c|c|c|c|c|}
\hline$r$ & & Dissolved Fe & Particulate Fe & Dissolved Mn & Particulate Mn \\
\hline \multirow[t]{4}{*}{ Dissolved } & $\mathrm{Cd}$ & $0.226^{* *}$ & - & 0.150 & - \\
\hline & $\mathrm{Cu}$ & 0.040 & - & 0.000 & - \\
\hline & $\mathrm{Zn}$ & $0.167^{*}$ & - & 0.100 & - \\
\hline & $\mathrm{Pb}$ & 0.017 & - & 0.131 & - \\
\hline \multirow[t]{4}{*}{ Particulate } & $\mathrm{Cd}$ & - & $0.669^{* *}$ & - & $0.621^{* *}$ \\
\hline & $\mathrm{Cu}$ & - & $0.921^{* *}$ & - & $0.884^{* *}$ \\
\hline & $\mathrm{Zn}$ & - & $0.532^{* *}$ & - & $0.476^{* *}$ \\
\hline & $\mathrm{Pb}$ & - & $0.988^{* *}$ & - & $0.909^{* *}$ \\
\hline
\end{tabular}

${ }^{* *}, p<0.01 ;{ }^{*}, p<0.05$ 
Table 3

The $\mathrm{LC}_{50}$ of $\mathrm{Cd}, \mathrm{Cu}, \mathrm{Zn}$, and $\mathrm{Pb}$ for the three organisms.

\begin{tabular}{|c|c|c|c|c|c|c|c|c|}
\hline & \multicolumn{8}{|l|}{$\mathrm{LC}_{50}$} \\
\hline & $\mathrm{Cd}$ & Reference & $\mathrm{Cu}$ & Reference & $\mathrm{Zn}$ & Reference & $\mathrm{Pb}$ & Reference \\
\hline Tubificid & $\begin{array}{l}11.8 \pm 3.8 \mu \mathrm{M} \\
(96 \mathrm{~h})\end{array}$ & $\begin{array}{l}\text { Mendez-Fernandez et al., } \\
2013\end{array}$ & $\begin{array}{l}0.002-0.158 \mathrm{mg} \mathrm{L}^{-1} \\
(96 \mathrm{~h})\end{array}$ & $\begin{array}{l}\text { Maestre et al., } \\
2009\end{array}$ & - & - & $\begin{array}{l}76.24 \mathrm{mg} \mathrm{L}^{-1} \\
(96 \mathrm{~h})\end{array}$ & Jiang et al., 2016 \\
\hline $\begin{array}{l}\text { Chironomid } \\
\text { larvae }\end{array}$ & $\begin{array}{l}9.38 \mathrm{mg} \mathrm{L}^{-1} \\
(24 \mathrm{~h})\end{array}$ & Bechard et al., 2008 & $2.09 \mathrm{mg} \mathrm{L}^{-1}(24 \mathrm{~h})$ & $\begin{array}{l}\text { Bechard et al., } \\
2008\end{array}$ & $\begin{array}{l}25 \mathrm{mg} \mathrm{L}^{-1} \\
(24 \mathrm{~h})\end{array}$ & $\begin{array}{l}\text { Bechard et al., } \\
2008\end{array}$ & $\begin{array}{l}0.61 \mathrm{mg} \mathrm{L}^{-1} \\
(24 \mathrm{~h})\end{array}$ & $\begin{array}{l}\text { Bechard et al., } \\
2008\end{array}$ \\
\hline Loach & $\begin{array}{l}56.5 \mathrm{mg} \mathrm{L}^{-1} \\
(96 \mathrm{~h})\end{array}$ & Wang et al., 2003 & $0.56 \mathrm{mg} \mathrm{L}^{-1}(96 \mathrm{~h})$ & Zhu et al., 2014 & $\begin{array}{l}2.86 \mathrm{mg} \mathrm{L}^{-1} \\
(96 \mathrm{~h})\end{array}$ & Zhu et al., 2014 & $\begin{array}{l}294.5 \mathrm{mg} \mathrm{L}^{-1} \\
(96 \mathrm{~h})\end{array}$ & $\begin{array}{l}\text { Wang et al., } \\
2003\end{array}$ \\
\hline
\end{tabular}

bioirrigation lead to the precipitation and adsorption of $\mathrm{Cd}, \mathrm{Zn}$ and $\mathrm{Pb}$ may be the major reason for reducing dissolved form of these heavy metals concentrations in the biological groups after $28 \mathrm{~d}$. Bioaccumulation of $\mathrm{Cd}, \mathrm{Cu}, \mathrm{Zn}$ and $\mathrm{Pb}$ by the three biological studies showed that the enrichment of tubificid was far greater than the other two organisms. Tubificid exposed to sediments accumulated significant quantities of $\mathrm{Cd}, \mathrm{Cu}, \mathrm{Zn}$ and $\mathrm{Pb}$ during the $28 \mathrm{~d}$ exposure, suggesting that tubificid inhabiting areas contaminated by $\mathrm{Cd}, \mathrm{Cu}$, $\mathrm{Zn}$ and $\mathrm{Pb}$ may provide a substantial dietary source of $\mathrm{Cd}, \mathrm{Cu}, \mathrm{Zn}$ and $\mathrm{Pb}$ for fish and other predators.

\section{Acknowledgments}

This study was sponsored by the National Natural Scientific Foundation of China (21677156, 41201498, 21107125, 51290282), the National Water Pollution Control and Treatment Science and Technology Major Project (2015ZX07205-003), and the special fund from the State Key Joint Laboratory of Environment Simulation and Pollution Control (Research Center for Eco-environmental Sciences, Chinese Academy of Sciences) (Project No. 16Z02ESPCR).

\section{References}

Alves, L.C., Borgmann, U., Dixon, D.G., 2009. Kinetics of uranium uptake in soft water and the effect of body size, bioaccumulation and toxicity to Hyalella azteca. Environ. Pollut. 157, 2239-2247.

Amato, E.D., Simpson, S.L., Remaili, T.M., Spadaro, D.A., Jarolimek, C.V., Jolley, D.F., 2016. Assessing the effects of bioturbation on metal bioavailability in contaminated sediments by diffusive gradients in thin films (DGT). Environ. Sci. Technol. 50, 3055-3064.

Atkinson, C.A., Jolley, D.F., Simpson, S.L., 2007. Effect of overlying water pH, dissolved oxygen, salinity and sediment disturbances on metal release and sequestration from metal contaminated marine sediments. Chemosphere 69, 1428-1437.

Banta, G.T., Andersen, O., 2003. Bioturbation and the fate of sediment pollutants experimental case studies of selected infauna species. Vie Milieu 53, 233-248.

Bechard, K.M., Gillis, P.L., Wood, C.M., 2008. Acute toxicity of waterborne Cd, Cu, Pb, $\mathrm{Ni}$, and $\mathrm{Zn}$ to first-instar Chironomus riparius larvae. Arch. Environ. Contam. Toxicol. 54, 454-459.

Blankson, E.R., Klerks, P.L., 2016. The effect of bioturbation by Lumbriculus variegatus on transport and distribution of lead in a freshwater microcosm. Environ. Toxicol. Chem. 35, 1123-1129.

Boekhold, A.E., Temminghoff, E.J.M., Vanderzee, S., 1993. Influence of electrolytecomposition and $\mathrm{pH}$ on cadmium sorption by an acid sandy soil. J. Soil Sci. 44, 85-96.

Bosch, A.C., O'Neill, B., Sigge, G.O., Kerwath, S.E., Hoffman, L.C., 2016. Heavy metals in marine fish meat and consumer health: a review. J. Sci. Food. Agr. 96, 32-48.

Brumbaugh, W.G., Besser, J.M., Ingersoll, C.G., May, T.W., Ivey, C.D., Schlekat, C.E., Garman, E.R., 2013. Preparation and characterization of nickel-spiked freshwater sediments for toxicity tests: toward more environmentally realistic nickel partitioning. Environ. Toxicol. Chem. 32, 2482-2494.

Buzier, R., Tusseau-Vuillemin, M.H., Mouchel, J.M., 2006. Evaluation of DGT as a metal speciation tool in wastewater. Sci. Total Environ. 358, 277-285.

Calmano, W., Hong, J., Forstner, U., 1993. Binding and mobilization of heavy-metals in contaminated sediments affected by ph and redox potential. Water Sci. Technol. 28, 223-235.

Cardoso, P.G., Lillebo, A.I., Lopes, C.B., Pereira, E., Duarte, A.C., Pardal, M.A., 2008. Influence of bioturbation by Hediste diversicolor on mercury fluxes from estuarine sediments: a mesocosms laboratory experiment. Mar. Pollut. Bull. 56, 325-334.

Chapman, P.M., Wang, F.Y., Janssen, C., Persoone, G., Allen, H.E., 1998. Ecotoxicology of metals in aquatic sediments: binding and release, bioavailability, risk assessment, and remediation. Can. J. Fish. Aquat. Sci. 55, 2221-2243.

Ciutat, A., 2003. Impact de La Bioturbation Des S Diments Sur Les Transfers et La Biodisponibilite Des M Taux. University Bordeaux 1, Bordeaux France.

Ciutat, A., Anschutz, P., Gerino, M., Boudou, A., 2005. Effects of bioturbation on cadmium transfer and distribution into freshwater sediments. Environ. Toxicol. Chem. 24, 1048-1058.

Ciutat, A., Boudou, A., 2003. Bioturbation effects on cadmium and zinc transfers from a contaminated sediment and on metal bioavailability to benthic bivalves. Environ. Toxicol. Chem. 22, 1574-1581.

Denney, S., Sherwood, J., Leyden, J., 1999. In situ measurements of labile Cu, Cd and $\mathrm{Mn}$ in river waters using DGT. Sci. Total Environ. 239, 71-80.

Dong, D.M., Nelson, Y.M., Lion, L.W., Shuler, M.L., Ghiorse, W.C., 2000. Adsorption of $\mathrm{Pb}$ and $\mathrm{Cd}$ onto metal oxides and organic material in natural surface coatings as determined by selective extractions: new evidence for the importance of $\mathrm{Mn}$ and Fe oxides. Water Res. 34, 427-436.

Du Laing, G., Rinklebe, J., Vandecasteele, B., Meers, E., Tack, F.M.G., 2009. Trace metal behaviour in estuarine and riverine floodplain soils and sediments: a review. Sci. Total Environ. 407, 3972-3985.

Duquesne, S., Newton, L.C., Giusti, L., Marriott, S.B., Staerk, H.-J., Bird, D.J., 2006 Evidence for declining levels of heavy-metals in the Severn Estuary and Bristol Channel, UK and their spatial distribution in sediments. Environ. Pollut. 143, 187-196.

Gambrell, R.P., Wiesepape, J.B., Patrick, W.H., Duff, M.C., 1991. The effects of pH, redox, and salinity on metal release from a contaminated sediment. Water Air Soil Poll. 57, 359-367.

Granberg, M.E., Gunnarsson, J.S., Hedman, J.E., Rosenberg, R., Jonsson, P., 2008 Bioturbation-driven release of organic contaminants from baltic sea sediments mediated by the invading polychaete marenzelleria neglecta. Environ. Sci. Technol. 42, 1058-1065.

He, Y., Men, B., Yang, X., Wang, D., 2015. Bioturbation/bioirrigation effect on thallium released from reservoir sediment by different organism types. Sci. Total Environ. 532, 617-624.

Hedman, J.E., Bradshaw, C., Thorsson, M.H., Gilek, M., Gunnarsson, J.S., 2008. Fate of contaminants in Baltic Sea sediments: role of bioturbation and settling organic matter. Mar. Ecol. Prog. Ser. 356, 25-38.

Hodgson, J.F., Tiller, K.G., Fellows, M., 1964. The Role of hydrolysis in the reaction of heavy metals with soil-forming materials. Soil Sci. Soc. Am. J. 28, 42-46.

Inskeep, W.P., Baham, J., 1983. Adsorption of Cd(II) and Cu(II) by na-montmorillonite at low surface coverage. Soil Sci. Soc. Am. J. 47, 660-665.

Jiang, D., Li, M., Cui, Y., 2016. Acute toxic effects of heavy metals and chlorophenols on Limnodrilus hoffmeisteri and safety assessment of the aquatic environment. China Environ. Sci. 34, 1572-4578 (in Chinese).

Josefsson, S., Leonardsson, K., Gunnarsson, J.S., Wiberg, K., 2010. Bioturbationdriven release of buried PCBs and PBDEs from different depths in contaminated sediments. Environ. Sci. Technol. 44, 7456-7464.

Kristensen, E., 2001. Impact of polychaetes (Nereis spp. and Arenicola marina) on carbon biogeochemistry in coastal marine sediments. Geochem. Trans. 2, 92-92.

Lagauzère, S., Boyer, P., Stora, G., Bonzom, J.M., 2009. Effects of uraniumcontaminated sediments on the bioturbation activity of Chironomus riparius larvae (Insecta, Diptera) and Tubifex tubifex worms (Annelida, Tubificidae). Chemosphere 76, 324-334.

Lewandowski, J., Hupfer, M., 2005. Effect of macrozoobenthos on two-dimensional small-scale heterogeneity of pore water phosphorus concentrations in lake sediments: a laboratory study. Limnol. Oceanogr. 50, 1106-1118.

Limited, D.R., Practical Guide for Using DGT for Metals in Waters Website.

Luoma, S.N., 1989. Can we determine the biological availability of sediment-bound trace-elements. Hydrobiologia 176, 379-396.

Lv, J., 2009. Effects of Tubificid Bioturbation on the Release and Speciation of Heavy Metals in Sediment. Jilin University, Changchun (in Chinese).

Ma, Y.j., Wan, G., 1999. Study on trace heavy metal diffusion at sediment-water interface and its effects on overlying lake water quality. Environ. Sci. 20, 7-11 (in Chinese).

Maestre, Z., Martinez-Madrid, M., Rodriguez, P., 2009. Monitoring the sensitivity of the oligochaete Tubifex tubifex in laboratory cultures using three toxicants. Ecotoxicol. Environ. Saf. 72, 2083-2089.

Mendez-Fernandez, L., Martinez-Madrid, M., Rodriguez, P., 2013. Toxicity and critical body residues of $\mathrm{Cd}, \mathrm{Cu}$ and $\mathrm{Cr}$ in the aquatic oligochaete Tubifex tubifex (Muller) based on lethal and sublethal effects. Ecotoxicology 22, 1445-1460. 
Mostofa, K.G., Liu, C.-q., Feng, X., Yoshioka, T., Vione, D., Pan, X., Wu, F., 2013 Complexation of dissolved organic matter with trace metal ions in natura waters. In: Mostofa, K.M.G., Yoshioka, T., Mottaleb, A., Vione, D. (Eds.), Photobiogeochemistry of Organic Matter. Springer, Berlin Heidelberg, pp. 769-849.

Ospina Alvarez, N., Glaz, L., Dmowski, K., Krasnodebska-Ostrega, B., 2014. Mobility of toxic elements in carbonate sediments from a mining area in Poland. Environ. Chem. Lett. 12, 435-441.

Peterson, G.S., Ankley, G.T., Leonard, E.N., 1996. Effect of bioturbation on metalsulfide oxidation in surficial freshwater sediments. Environ. Toxicol. Chem. 15, 2147-2155.

Qiao, Q., 2011. Study on the Influence Factors of the Speciation and Release of Heavy Metals in Sediment with Tubificid Bioturbation. Jilin University, Changchun (in Chinese).

Rasmussen, A.D., Banta, G.T., Andersen, O., 2000. Cadmium dynamics in estuarine sediments: effects of salinity and lugworm bioturbation. Environ. Toxicol. Chem. 19, 380-386.

Remaili, T.M., Simpson, S.L., Amato, E.D., Spadaro, D.A., Jarolimek, C.V., Jolley, D.F., 2016. The impact of sediment bioturbation by secondary organisms on meta bioavailability, bioaccumulation and toxicity to target organisms in benthic bioassays: implications for sediment quality assessment. Environ. Pollut. Part B 208, 590-599.

Roulier, J.L., Tusseau-Vuillemin, M.H., Coquery, M., Geffard, O., Garric, J., 2008 Measurement of dynamic mobilization of trace metals in sediments using DGT and comparison with bioaccumulation in Chironomus riparius: first results of an experimental study. Chemosphere 70, 925-932.

Schaller, J., 2014. Bioturbation/bioirrigation by Chironomus plumosus as main factor controlling elemental remobilization from aquatic sediments? Chemosphere $107,336-343$.

Schaller, J., Dharamshi, J., Dudel, E.G., 2011. Enhanced metal and metalloid concentrations in the gut system comparing to remaining tissues of Gammarus pulex L. Chemosphere 83, 627-631.

Schaller, J., Weiske, A., Mkandawire, M., Dudel, E.G., 2010. Invertebrates control metals and arsenic sequestration as ecosystem engineers. Chemosphere 79 169-173.

Shull, D.H., Benoit, J.M., Wojcik, C., Senning, J.R., 2009. Infaunal burrow ventilation and pore-water transport in muddy sediments. Estuar. Coast. Shelf Sci 83 $277-286$

Simpson, S.L., 2005. Exposure-effect model for calculating copper effect concentrations in Sediments with varying copper binding properties: a synthesis Environ. Sci. Technol. 39, 7089-7096.

Simpson, S.L., Batley, G.E., 2003. Disturbances to metal partitioning during toxicity testing of iron(II)-rich estuarine pore waters and whole sediments. Environ. Toxicol. Chem. 22, 424-432.

Simpson, S.L., Yverneau, H., Cremazy, A., Jarolimek, C.V., Price, H.L., Jolley, D.F. 2012. DGT-induced copper flux predicts bioaccumulation and toxicity to bivalves in sediments with varying properties. Environ. Sci. Technol. 46, 9038-9046.

Taylor, D., 1983. The significance of the accumulation of cadmium by aquatic organisms. Ecotoxicol. Environ. Saf. 7, 33-42.

Tessier, A., Campbell, P., 1988. Partitioning of trace metals in sediments. In: Kramer, J.R., Allen, H.E. (Eds.), Metal Speciation: Theory, Analysis and Application. Lewis Publisher, Chelsea, MI, USA, pp. 183-199.

Tessier, A., Couillard, Y., Campbell, P.G.C., Auclair, J.C., 1993. Modeling cd partitioning in oxic lake-sediments and cd concentrations in the fresh-water bivalve anodonta-grandis. Limnol. Oceanogr. 38, 1-17.

Tessier, L., Vaillancourt, G., Pazdernik, L., 1994. Comparative-study of the cadmium and mercury kinetics between the short-lived gastropod viviparus-geogianus (lea) and pelecypod elliptio-complanata (lightfoot), under laboratory conditions. Environ. Pollut. 85, 271-282.

Thibodeaux, L.J., Bierman, V.J., 2003. The bioturbation-driven chemical release process. Environ. Sci. Technol. 37, 252A-258A.

Thorne, L.T., Nickless, G., 1981. The relation between heavy-metals and particle-size fractions within the severn estuary (UK) inter-tidal sediments. Sci. Total Environ. 19, 207-213.

Timmermans, K.R., Vanhattum, B., Kraak, M.H.S., Davids, C., 1989. Trace-metals in a littoral foodweb - concentrations in organisms, sediment and water. Sci. Total Environ. 87-88, 477-494.

Turner, A., Millward, G.E., Le Roux, S.M., 2004. Significance of oxides and particulate organic matter in controlling trace metal partitioning in a contaminated estuary. Mar. Chem. 88, 179-192.

van Hattum, B., Timmermans, K.R., Govers, H.A., 1991. Abiotic and biotic factors influencing in situ trace metal levels in macroinvertebrates in freshwater ecosystems. Environ. Toxicol. Chem. 10, 275-292.

Wall, S.B., Isely, J.J., LaPoint, T.W., 1996. Fish bioturbation of cadmium-contaminated sediments: factors affecting cd availability to Daphnia magna. Environ. Toxicol. Chem. 15, 294-298.

Wang, Y., Zhang, Y., Zhao, D., 2003. Effects of heavy metals cadmium, lead and zinc on the survival of Carassius Auratus and Misgurnus Anguillicaudatus. J. Gansu Sci. 15, 35-38 (in Chinese).

Zhu, X., Chen, L., Chen, Y., Lu, S., 2014. Acute toxicity and joint toxicity of $\mathrm{Cu}^{2+}, \mathrm{Al}^{3+}$ and $\mathrm{Zn}^{2+}$ to loach. Environ. Sci. Technol. 37 (26-29), 37-47 (in Chinese).

Zoumis, T., Schmidt, A., Grigorova, L., Calmano, W., 2001. Contaminants in sediments: remobilisation and demobilisation. Sci. Total Environ. 266, 195-202. 